\title{
二成分混合燃料のソノケミストリーによる改質過程の 気泡崩壊時エネルギに関するモデリング*
}

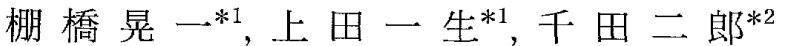

\section{Energy Modelling on Cavitation Bubble Collapse Process for Two-Component Fuel Reformulation by Use of Sonochemistry}

\author{
Koichi TANAHASHI*3, Kazuo UEDA and Jiro SENDA \\ *33 Department of Mechanical Engineering, Doshisha University, \\ 1-3 Tataramiyakodani, Kyotanabe-shi, Kyoto, 610 0321 Japan
}

\begin{abstract}
The origin of Sonochemistry is an acoustic cavitation process in the liquid phase ; those are the nucleation, growth and violent collapse. Here, instantaneous hot-spot with high temperature and pressure is generated in the local region by the bubble collapse. The authors have proposed to apply the sonochemistry into a heavy fuel oil mixed with a lower boiling point fuel for reformulation of the heavy fuel oil and reported the advantage of the mixed fuel. Thus, the several experimental results relating to the fuel reformulation in the previous studies. Then, it is necessary to clarify a theoretical analysis for reformulation process based on cavitation dynamics. Therefore, the authors develop an energy modeling on the cavitation bubble collapse have process for reformulation of two ${ }^{-}$component fuel by use of Sonochemistry. And it is confirmed that reformulation efficiency of mixed fuel is higher than that of the pure fuel case.
\end{abstract}

Key Words : Cavitation, Bubble, Sonochemistry, Numerical Simulation, Collapse Energy

\section{1. 緒言}

ソノケミストリー(以下，SC)とは，超音波キャビテ ーション気泡の崩壊現象がもたらす特異な化学反応を 指す ${ }^{(1)}$. 例えば，溶液内に超音波を照射すると，図 1 に示すような圧力変動が生じ，負圧側にて，溶存気体 を核とし，蒸気気泡が生成する.この気泡は周囲の圧 力変動に追従して，膨張収縮を繰り返し，やがて，急 激に崩壊する. この際, 数 $\mu \mathrm{m}$ 程度の局所な領域で, 高 温・高圧場が形成され，熱分解反忘や発光現象が生じ $ろ^{(1)(5)}$.この現象を然料に適用すると，炭素結合が開裂 し，低分量成分一と改質される．ところが，気泡崩壊 時に生じる温度が，改質効果を左右する重要な因子で はあるものの，局所的な場であるため，直接測定され ていないばかりか, 光学的手法や化学反応速度からの 見積もりに留まり，その詳細が不明である。

このような中，これまで様々な理論に基づいた多く の気泡崩壊温度のモデルが提案されている ${ }^{((9)}$ が, 発泡 気泡数を考慮しないことに加え，その現象の複雑さゆ えに，あらゆる現象に対し合致寸る確固たるモデルは

\footnotetext{
* 原稿受付 2009 年 3 月 16 日.

*1 正員, 同志社大学大学院工学研究科 (更610-0321 京田辺市 多々羅都谷 1-3).

*2 正員, フェロー, 同志社大学理工学部.

E-mail : jsenda@mail.doshisha.ac.jp
}

構筑されていない. 特に, Mizukoshi ら ${ }^{(10) や}$ Suslick $^{(1)} ら$ が指摘する溶液のある蒸気王にて，改質効果が最大と なることに加え，この特性が溶液に投入した超音波の エネルギに左右されるとの報告もあり(11)，SCに関する 現象を解明するためにも，蒸気圧に起因した改質効果 の特性を勘案したモデルの構築が切望される.

これまで著者の一人 ${ }^{(12)(19)}$ は，キャビテーション気泡 の崩壊が起因した種々の現象に対し，気泡動力学に基 づき解析を行なってきた。 また, 本研究では, 石油精 製時に副生成される重質系燃料を SC により改質する ことを試みており，上述した蒸気王に起因した改質効 果の特性を生かすため，ガソリンや軽油などの低沸点 燃料を混合し，その結果，混合然料の蒸気圧向上とい

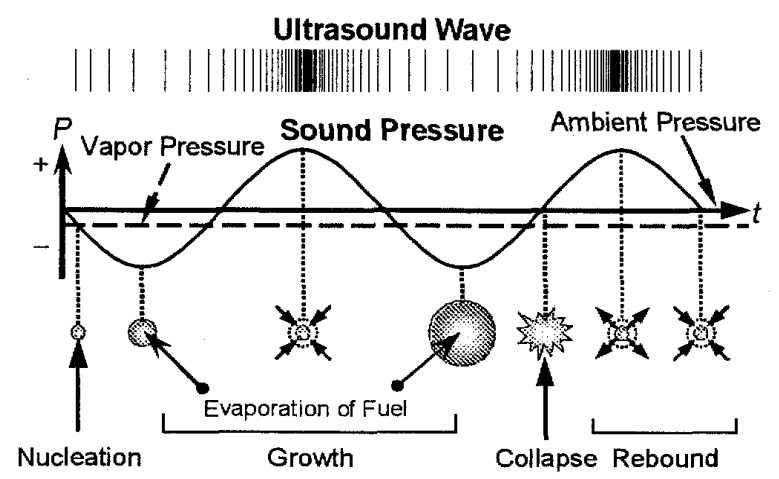

Fig. 1 Acoustic cavitation growth process from nucleation to collapse 
う特性により改質効率が向上するとの知見を得た ${ }^{(17)}$. しかしながら，従来のモデルでは，蒝気圧がおよぼす 改質効果一の影響につい, 詳細な解析が行なえない.

そこで本論文では，二成分混合燃料老対象とし，核 生成, 気泡成長，気泡崩壊までの過程を全て考慮した $\mathrm{SC}$ における気泡崩壊時のエネルギに関寸るモデルを 構築し, 数值解析在行なった. さらに, 超音波然料改 質による実験結果との比較を行ない，本モデルの妥当 性を検証した。

\section{2. 気泡崩壊時のエネルギモデル}

本研究で構築した気泡崩壊時のエネルギモデルの概 略を图 2 に示す. 本モデルでは，(1)気泡の生成数に関 寸る計算を行い，次に(2)キャビテーション気泡の成長 に関する計算を行う. そして気泡成長速度が負, つま り気泡が収縮過程ならば次の計算に移る. (3)気泡内に 存在する混合然料の比熱比に関する計算を行い, 最終 的に(4)気泡崩壊時のエネルギを算出寸る. なお，進行 波音場において超音波ホーンから気泡が発生している ことを前提としている. 単一気泡の成長・崩壊は, Rayleigh-Plesset 方程式から派生した Keller の式孝用い て解いた．なお，本モデルの構築にあたり，用いた仮 定を以下に示す。

（1）各気泡それぞれの合体，分裂は考慮しない.

（2）発泡した気泡は全て崩壊する.

(3) 周囲圧の圧力上昇速度が速く, 気泡内の燃料蒸気 が㠜樎する前に気泡崩壊を生じる。

（4）気泡核の生成は溶液中に溶解する不凝縮性の溶存 気体の析出により生じる.

(5) 気泡界面の温度は, 液体の温度と等しい。

(6) 気泡内部は温度, 圧力ともに均一である.

（7）気泡内の比熱比は，気泡の大きさにより変化する.

$2 \cdot 1$ 混合燃料の物性值推算 本論文では, 物性が 異なる相互溶解可能な燃料同士の混合寸なわち多成分 化した燃料における各温度での輸送物性值や蒸気圧を 算出寸る必要がある. そこで本論文では，各物性值を NIST Mixture Property Database ${ }^{(18)}$ より推算した. 但し, 表面張力のに関しては，本プログラムで算出できない ため，以下に示す推算式 ${ }^{(19)}$ 上り求めた。

$$
\sigma_{m l}^{1 / 4}=\sum_{i=1}^{n}\left[P_{i}\right] \cdot\left(\rho_{l m} x_{i}-\rho_{v m} y_{i}\right)
$$

ここで, $\sigma_{m l}[\mathrm{~N} / \mathrm{m}]$ 法混合然料の表面張力, $i$ 注各化学種, $\left[P_{i}\right]$ は $i$ 成分のパラコール, $\rho_{m}, \rho_{m}\left[\mathrm{~mol} / \mathrm{m}^{3}\right]$ は混合燃料 の液相および気相の分子密度， $x_{i}, y_{i}$ は液相および気相 における $i$ 成分のモル分率をそれぞれ示す．また，蒸気 圧の推算には，以下に示寸修正 $\mathrm{BWR}^{(20)}$ 上り求めた.

$$
\begin{aligned}
& P=R T \rho_{l}+\left(B_{0} R T-A_{0}-\frac{C_{0}}{T^{2}}+\frac{D_{0}}{T^{3}}+\frac{E_{0}}{T^{4}}\right) \rho_{l}^{2} \\
& +\left(b R T-a-d / T-e / T^{4}-f / T^{23}\right) \rho_{l}^{3} \\
& +\alpha\left(a R T+d / T+e / T^{4}+f / T^{23}\right) \rho_{l}^{6} \\
& +\left(c / T^{2}+g / T^{8}+h / T^{17}\right) \rho_{l}^{3}\left(1+\gamma \rho^{2}\right) \exp \left(-\gamma \rho^{2}\right)
\end{aligned}
$$

ここで, $P[\mathrm{MPa}]$ は圧力， $R[\mathrm{~J} / \mathrm{kg} \cdot \mathrm{K}]$ はガス定数， $T[\mathrm{~K}]$ は 温度をそれぞれ示す．なお，上記以外の記号注，燃料 の種類および温度により決まる定数であり，その詳細 は参考文献(20)に詳しい。

気液平衡の計算結果の一例として, $\mathrm{n}$-デカン

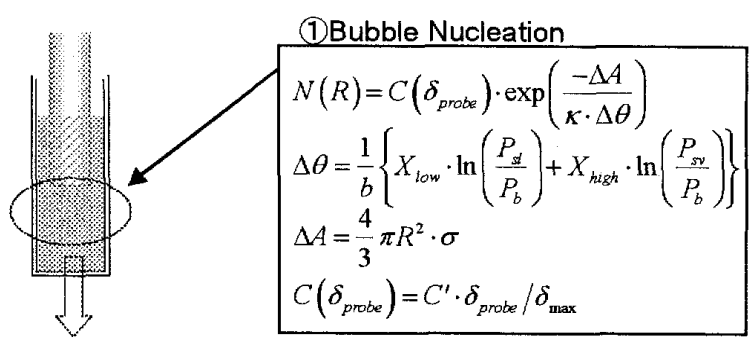

Cavitation Bubble Growth

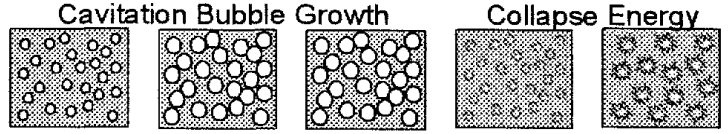

(2) Cavitation Bubble Growth

$R \ddot{R}^{2}\left(1-\dot{R}^{2} / c_{l}\right)+3 / 2 \dot{R}^{2}\left(1-\dot{R} / 3 c_{l}\right)=\left(1+\dot{R} / c_{l}+R / c_{l} \cdot \frac{d}{d t}\right) \frac{P}{\rho_{l}}$
$P=P_{v}+\left(P_{0}+\frac{2 \sigma}{R_{0}}\right)\left(\frac{R_{0}}{R}\right)^{3 y}-\frac{2 \sigma}{R}-\frac{4 \mu R}{R}-\left(P_{\text {anb }}-P_{a} \sin (2 \pi f t)\right)$

(3) Specific heat ratio (4) Collapse Energy

$\left.\begin{array}{c}\kappa_{i}=h_{i} \cdot\left[\frac{P_{e t}}{60000}\right]+1 \quad P_{e}=\frac{R_{0}^{2} \dot{R}}{R \alpha} \\ \gamma=\kappa_{0}\left(\frac{V_{0}}{V_{\max }}\right)+\sum_{i} \kappa_{i} \cdot X_{i} \times\left(\frac{V_{\max }-V_{0}}{V_{\max }}\right)\end{array}\right] \begin{aligned} & T_{\max }=T_{0}\left(\frac{R_{\max }}{R_{i r k}}\right)^{3(\gamma-1)} \\ & E_{\text {oct }}=C_{v}\left(T_{\max }-T_{0}\right) \\ & E_{t o l}=N(R) \times E_{c o l}\end{aligned}$

Calculation procedure

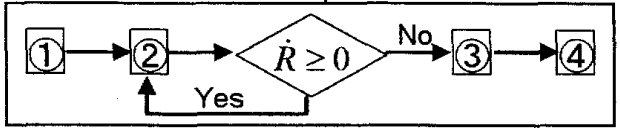

Fig.2 Schematic of energy model for cavitation collapse

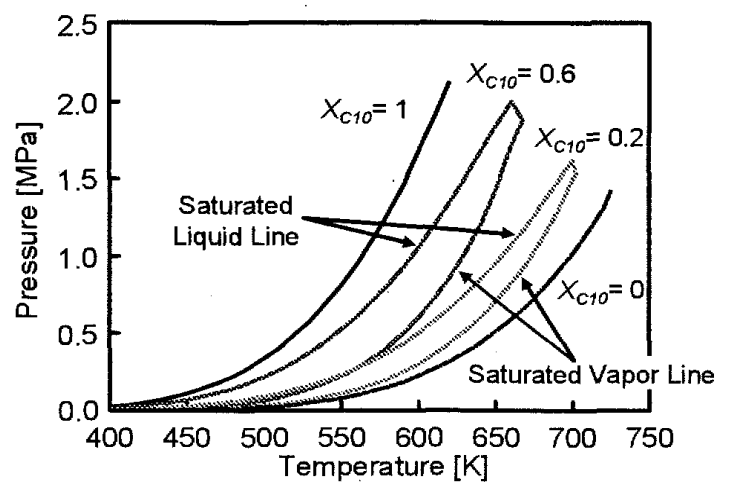

Fig. 3 Pressure-temperature diagram of pure fuel and mixed fuel of $\mathrm{n}$-docane and $\mathrm{n}$-hexadecane 
$\left(\mathrm{n}-\mathrm{C}_{10} \mathrm{H}_{22}\right)$ およびn一へキサデカン $\left(\mathrm{n}-\mathrm{C}_{16} \mathrm{H}_{34}\right)$ ，それらの混 合然料 $\left(C 16 / C 10, \mathrm{n}-\right.$-゙゙カンの混合割合 $\left.X_{C l \sigma}=0.2,0.6\right)$ の 温度一压力線図をそれぞれ図 3 に示す．図に示寸よう に，単成分然料の飽和蒸気压曲線は 1 本の曲線で描汃 れているのに対し，混合然料の飽和蒸気圧曲線は，飽 和液体曲線と飽和蒸気曲線からなる気液二相領域を形 成する.なお，本論文ではこれ以降，混合然料の蒸気 圧は飽和液体曲線上の圧力とする。

$2 \cdot 2$ 気泡核生成モデル 気泡核生成は, 純粋溶液 の分子間力に相当する減压により生成する均一核生成 と, 液体中に存在寸る微少量の混入気体や溶存気体に より生成寸る不均一核生成に大別される. 本論文では 最も生成頻度が高いと思われる，溶存気体に起因寸る 不均一核生成のみを考慮する。一般に，過熱度 $\Delta \theta[\mathrm{K}]$ が与えられた溶夜中において，半径 $R[\mu \mathrm{m}]$ 学持つ単位 体積における発泡気泡核数 $N(R)$ [個数]忙，核生成理論 より(21)次式で与えられる.

$$
\begin{aligned}
& N(R)=C\left(\delta_{\text {probe }}\right) \times \exp \left(\frac{-\Delta A}{\kappa \cdot \Delta \theta}\right) \\
& \Delta A=\frac{4}{3} \pi R^{2} \cdot \sigma_{l}
\end{aligned}
$$

ここで, $C\left(\delta_{p r b b e}\right)$ は振幅ごとに決まる無次元定数, $\kappa[\mathrm{J} / \mathrm{K}]$ はボルツマン定数, $\sigma_{l}[\mathrm{~N} / \mathrm{m}]$ は気液界面での表面張力を それぞれ示す。

また，気泡の成長により熱を奪われ燃料温度が雰囲 気温度より降下すれば，(3)式中の過熱度 $\Delta \theta$ は図 4 に 示寸ように燃料温度 $\theta_{f}$ 上減王状態における液体の蒸発 温度との差であり，飽和蒸気圧 $P_{v}[\mathrm{~Pa}]$ と減圧場の雾囲 気圧 $P_{b}[\mathrm{~Pa}]$ 用いて, 次式のように表すことができる ${ }^{(14)}$.

$$
\Delta \theta=1 / g \cdot \ln \left(P_{v} / P_{b}\right)
$$

ここで， $g$ は燃料により定まる定数である．なお，(5) 式弾成分然料のみを記述した場合であり，二成分混 合燃料の場合，先述の気液二相領域を考慮して，以下 の式より求めた.

$$
\Delta \theta=\frac{1}{g}\left\{X_{\text {low }} \cdot \ln \left(\frac{P_{s l}}{P_{b}}\right)+X_{\text {high }} \cdot \ln \left(\frac{P_{s v}}{P_{b}}\right)\right\}
$$

ここで, $X_{\text {low }}$ と $X_{\text {high }}$ は, 低沸点成分と高沸点成分の混 合割合, $P_{s l}[\mathrm{~Pa}]$ は飽和液体曲線上の圧力, $P_{s v}[\mathrm{~Pa}]$ 鴒和 蒸気曲線上の圧力をそれぞれ示す，厳密には二相領域 内まで周囲圧力が低下寸ると，高进点成分も少なから ず蒸発する. しかしながら，蒝発量が微少量であるこ とから(6)式のように定義した。

また, 減圧場の雾囲気圧 $P_{b}[\mathrm{~Pa}]$ は音圧の変動により 与えられ，ソノケミストリーの効果が現れる最低音圧
は大気圧以上であることから ${ }^{(22)}$ ，絶刘真空以下となる。 そこで，超音波ホーンの振動振幅 $\delta_{\text {probe }}[\mu \mathrm{m}]$ 妾用いて， 減圧場の雾囲気圧 $P_{b}$ を次式のように定義した.

$$
P_{b}=1 \times 10^{-4} \cdot\left(2-\delta_{\text {probe }} / \delta_{\max }\right)
$$

ここで， $\delta_{\text {max }}[\mu \mathrm{am}]$ は超音波照射に用いるホーンの最大振 動振幅であり，本論文ではこれ以降， $\delta_{\max }=124 \mu \mathrm{m}$ の超 音波ホーン用いるものとする.

成長可能な最小気泡核半径 $R_{c}[\mu \mathrm{m}]$ は, 次の Laplace-Kelvin ${ }^{(23)}$ の式で与えられる.

$$
\frac{\rho_{l}-\rho_{v}}{\rho_{l}}\left(P_{w}-P_{r}\right)=\frac{2 \sigma_{l}}{R_{c}}
$$

ここで， $\rho_{[}\left[\mathrm{kg} / \mathrm{m}^{3}\right]^{3}$ 夜体の密度， $\rho_{i}\left[\mathrm{~kg} / \mathrm{m}^{3}\right]$ 気体の密度, $P_{w}[\mathrm{~Pa}]$ は気泡壁の圧力, $P_{r}[\mathrm{~Pa}]$ は気泡から無限遠におけ る溶液の圧力をそれぞれ示す。

(8)式より，最小减圧場における雾囲気圧すなわち $P_{b}=1.0 \times 10^{-4}$ の引張圧力 $P_{\mathrm{w}}-P_{r}$ で正規化した各引張王力 の值と最小発泡気泡核半径 $R_{c}$ の変化の計算結果を図 5 に示す，なお，計算は $\mathrm{n}$-へキサデカン, n-デカンおよ び $C 16 / C 10\left(X_{C 10}=0.4\right)$ で行ない, $P_{w}$ には燃料蒸気圧を与 えた.この結果より,本条件に対する最小の $R_{c}$ は $0.8 \mathrm{rm}$ 程度となり，本論文では $1 \mu \mathrm{m}$ 以上を気泡榜半径として 取り扱うことにする.

次に, 気泡群の背景光撮影実験の結果を参考にして,

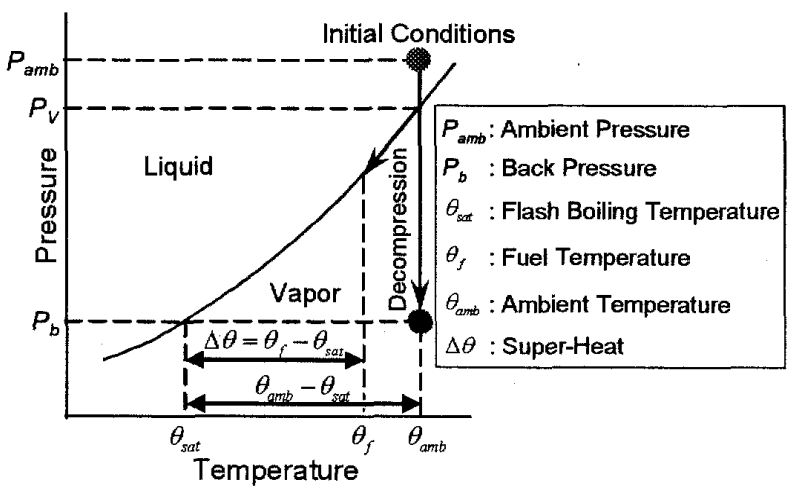

Fig.4 Schematic diagram of definition for degree of super-heat

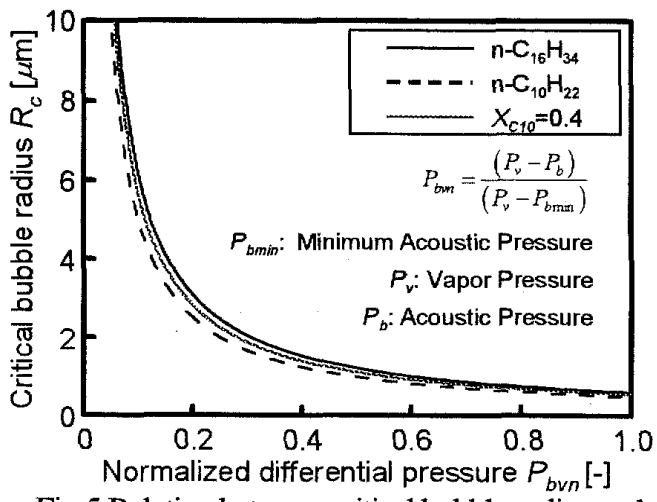

Fig. 5 Relation between critical bubble radius and normalized differential pressure 
(3)式における $C\left(\delta_{\text {probe }}\right)$ の值を算定寸る.なお，撮影実 験の方法および条件は次章に記述する，得られた気 泡画像上り，発泡気泡核数怯，同一の振動振幅におけ る差がそれほど無く，過熱度のみに依存している.

したがって, $C\left(\delta_{\text {probe }}\right)$ は, 超音波ホーンの振動振幅 $\delta_{\text {probe }}$ $[\mu \mathrm{m}]$ およよび最大の振動振幅 $\delta_{\max }[\mathrm{\mu m}]$ を用いて次式の上 うに定義される.

$$
C\left(\delta_{\text {probe }}\right)=C^{\prime} \times \delta_{\text {probe }} / \delta_{\max }
$$

ここで，C'の詳細な值は，得られた画像からも正確に は判断し難く, 本モデルでは，最大発泡数の値で正規 化した. 寸なわち， $C^{\prime}=1$ とした.

$2 \cdot 3$ 気泡成長モデル超音波を照射した溶液中 における気泡の成長過程は，以下の Keller の式 ${ }^{(24)}$-゙求 められる。

$$
R \ddot{R}^{2}\left(1-\frac{\dot{R}^{2}}{C_{l}}\right)+\frac{3}{2} \dot{R}^{2}\left(1-\frac{\dot{R}}{3 C_{l}}\right)=\left(1+\frac{\dot{R}^{2}}{C_{l}}+\frac{\dot{R}}{C_{l}} \cdot \frac{d}{d t}\right) \frac{P}{\rho_{l}}
$$

ここで, $R[\mu \mathrm{m}]$ は気泡半径, $C_{l}[\mathrm{~m} / \mathrm{s}]$ は溶液の音速を表 す. $\rho_{1}\left[\mathrm{~kg} / \mathrm{m}^{3}\right] ， P[\mathrm{~Pa}]$ 洁気泡壁における気泡内圧力と無 限遠での流体圧力の差であり，次式で表せる.

$$
\begin{aligned}
& P=P_{v}+\left(P_{0}+\frac{2 \sigma_{l}}{R_{0}}\right)\left(\frac{R_{0}}{R}\right)^{3 r}-\frac{2 \sigma_{l}}{R_{0}}-\frac{4 \mu_{l} \dot{R}}{R}-P_{\mathcal{S}} \\
& P_{f}=P_{a n b}-P_{a} \sin (2 \pi f t)
\end{aligned}
$$

ここで， $P_{v}\left[\mathrm{~Pa} \mid\right.$ 计蒸気圧， $P_{0}\left[\mathrm{~Pa} \mid\right.$ 计音圧振幅， $R_{0}[\mu \mathrm{m}]$ は初期気泡半径, $\gamma$ は気泡内比熱比， $\mu_{4}[\mathrm{~Pa} \cdot \mathrm{s}]$ は液体の 粘性, $P_{a m b}[\mathrm{~Pa}]$ は大気圧, $P_{a}[\mathrm{~Pa}]$ は実行音圧, $f[\mathrm{~Hz}]$ は振 動周波数である. なお， $\gamma$ は次節で詳細な説明を行う。

実行音圧 $P_{a}=0.08,0.12,0.16,0.2 \mathrm{MPa}$ に対寸る気 泡半径の成長履歴の一例を, 縦軸に初期気泡半径で正 規化した気泡半径で図 6(a)に示す．なお，このときの 供試燃料は $C 16 / C 10$ 混合然料とし, 混合割合は $X_{C l \sigma}=0.2$ であり，図 6(b)にはそのときの圧力履歴を示寸，実行 音圧が低い条件では，気泡の成長が緩漫であり，比較 的早期に崩壊する。これは，気泡壁の圧力と周囲液体 圧力のバランスによるものである. また，先述したよ うに, 大気圧以下の実行音圧である $P_{a}=0.08 \mathrm{MPa}$ では, 急激な崩壊が生じないことが確認できる. 次に，初期 気泡径 $R_{\sigma}=10 \mu \mathrm{m}$ とした際の, $C 16 / C 10$ の各混合割合, 各音圧に対する気泡成長割合 $R_{\text {max }} / R_{0}$ の結果を図 7 に示 寸.なお， $R_{\text {max }}[\mathrm{rm}]$ とは，最大気泡径であり， $R_{0}$ は気 泡径分布をもちますが，最頻值に近い粒径 $R_{\sigma}=10 \mu \mathrm{m}^{[25]}$ 老代表気泡として採用しました，本論文 ではこれ以降，初期気泡径 $R_{\sigma}=10 \mu \mathrm{m}$ する. この図よ り，各音圧で，低沸点然料の混合割合が高くなるにつ れ， $R_{\text {max }} R_{0}$ の值が直線的に増加寸る．つまり，低沸点
燃料を混合すると，気泡が成長し難い重質系然料の気 泡成長を改善することができる.

$2 \cdot 4$ 気泡崩壊時に生じる温度 超音波照射場に おいて，生成した気泡は，減区期間において成長する 蒸気キャビテーション気泡であり，溶液内の圧力が大 気圧または雾囲気圧に戻り，加圧期間になると瞬時に 熱力学的バランスが崩れ，收縮し，球形振動から非球 形振動となり崩壊寸る.この際，気泡内部は準断熱圧 緶され，その内部は高温・高圧となる. Nolting-Neppiras ら ${ }^{(9)}$ によれば, 崩壊する直前の気泡内部 崩壊温度 $T_{\text {max }}[\mathrm{K}]$ は以下に示寸式で記述できる.

$$
T_{\max }=T_{0}\left(R_{\max } / R_{b r k}\right)^{3(\gamma-1)}
$$

ここで, $T_{0}[\mathrm{~K}]$ は周囲液体温度, $R_{b r k}[\mu \mathrm{m}]$ は崩壊時の気 泡径をそれぞれ示す．なお，本研究では，気泡が断熱

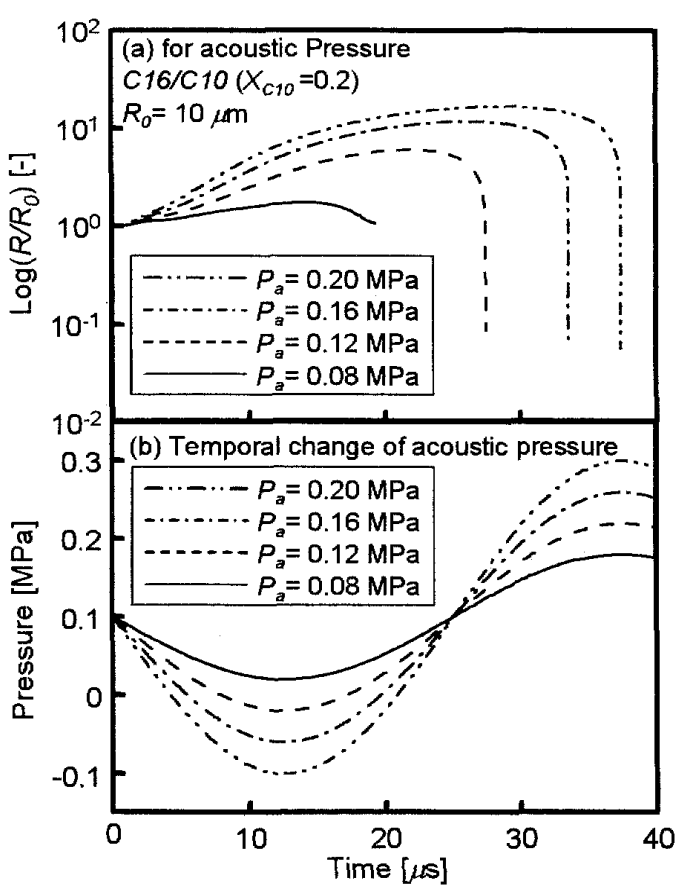

Fig.6 Temporal change in cavitation bubble radius under variable acoustic pressure

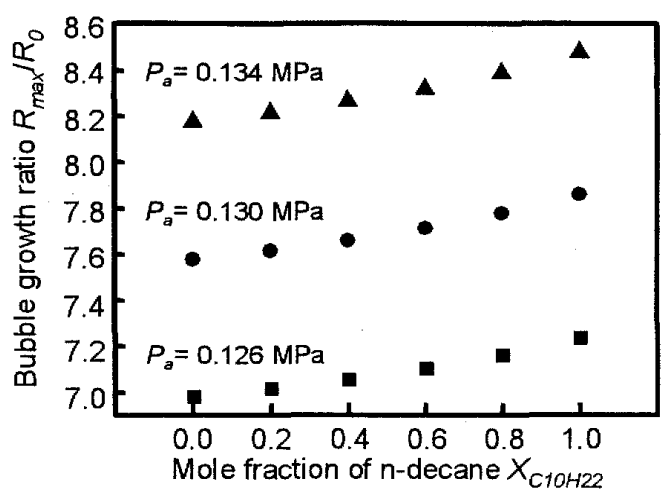

Fig. 7 Calculation result for bubble growth ratio with variable acoustic pressure for $\mathrm{C} 16 / \mathrm{ClO}$ 
的に膨張する際における気泡内温度の低下度合いを詳 細に把握することが難しいため, 最大気泡半径をとつ た時の気泡内温度は周囲液体温度 $T_{0}$ と仮定した. 崩壊 気泡径 $R_{b r k}$ に関しては，実験的には明らかれされてお らず，詳細な值が不明である. 一方, Rayleigh-Taylor ${ }^{(20)}$ の球形気泡の安定性理論によれば， $R_{0}$ 以下にまで収縮 した気泡は球形を保てず, 非球形振動となり，崩壊が 開始されるものの，非球形振動時においても気泡は収 縮しており，この収縮は振動モードすなわち超音波照 射場の複雑な現象に依存寸る. そこで, 本論文で取り 扱う最小気泡核半径である $1 \mu \mathrm{m}$ を崩壊気泡径とした.

また, Lohse ら (20)が指摘するように, 液体の圧縮性を 考慮すると，気泡の収縮速度は，溶液の音速を超える ほど高くない，つまり，気泡内比熱比は，瞬時に断熱 係数となるのではなく，気泡壁速度に依存した時間的 な変動があると考えられる. そこで, Lohse ら同様に比 熱比を気泡壁速度の関数として与えるため, Prosperetti ${ }^{(28)}$ が提案寸る Peclet 指数 $P_{e}$ を導入した.

$$
P_{e}=R_{0}^{2} \dot{R} / R \alpha
$$

ここでの $\dot{R}$ は収縮速度であり, Keller の式から算出し た。㤬熱拡散倸数であり，アルゴンでは $19.28 \mathrm{~m}^{2} / \mathrm{s}$, 空気では $19.0 \mathrm{~m}^{2} / \mathrm{s}$ となる. これを用いて，以下の式に て気泡内気体の比熱此 $\gamma$ を求めた.

$$
\begin{aligned}
& \kappa_{i}=h_{i} \cdot\left[\log \left(\frac{P_{e i}}{60000}\right)\right]+1 \\
& \gamma=\kappa_{0}\left(\frac{V_{0}}{V_{\max }}\right)+\sum_{i} \kappa_{i} \cdot X_{i} \times\left(\frac{V_{\max }-V_{0}}{V_{\max }}\right)
\end{aligned}
$$

ここで, $\kappa_{i}$ は各化学種の比熱比, $P_{e i}$ は各化学種の Peclet 指数, $h_{i}$ は化学種ごとに決まる定数, $\kappa_{0}$ は溶存気体の 比熱比, $V_{0}\left[\mu \mathrm{m}^{3}\right]$ は初期気泡体積, $V_{\text {max }}\left[\mu \mathrm{m}^{3}\right]$ は最大気泡 径での気泡体積， $X_{i}$ は溶液の混合割合をそれぞれ示す。

以上の手順に従い，気泡内比熱比および気泡崩壊時 の気泡内温度を求める. 一例として, $\mathbf{n}$-ヘキサデカン と $C 16 / C 10\left(X_{C l \sigma}=0.2,0.4,0.6,0.8\right)$ における比熱比を 横軸Peclet 指数 $P_{e}$ で整理したものを図 8 に示す. 各然 料ともに，収縮速度が増加するに伴ない気泡内比熱比 が向上寸る. 次に, 実行音圧 $P_{a}=0.126,0.13,0.134 \mathrm{MPa}$ に対し, 縦軸に気泡崩壊時に生じる温度を $P_{a}=0.134 \mathrm{MPa}, X_{C I 0}=0.0$ の計算值で正規化し, 横軸に混 合割合で整理したものを図 9 に示寸，なお，供試然料 は，先ほどの比熱比と同様である. 各音圧において， 低沸点燃料の混合割合が低下するにしたがい崩壊温度
は高い．この傾向は，気泡の成長割合とは逆であり， 気泡内比熱比と同じことから，崩壊温度は気泡内比熱 比の影響が支配的である. また, 低蒸気圧溶液の崩壊 温度が高いことが実験的に解明されており と一致する.

2 -5 気泡崩壊時に生じるエネルギ＼cjkstart先述した崩 壊温度により高エネルギが生じるならば, 熱力学のエ ネルギ式より, 1 つ気泡内の蒸気成分に与える崩壞時 エネルギ $E_{\text {cod }}[\mathrm{kJ} / \mathrm{kg}]$ は次式で表せる.

$$
E_{c o t}=C_{\nu}\left(T_{\max }-T_{0}\right)
$$

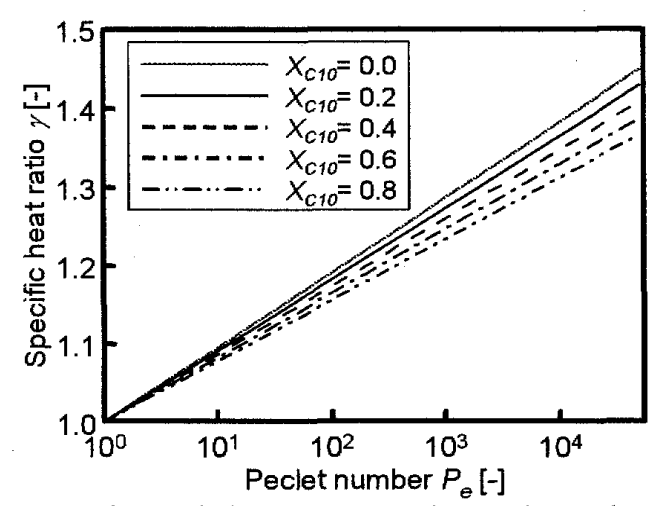

Fig.8 Relation between peclet number and specific heat ratio for $\mathrm{C} 16 / \mathrm{ClO}$

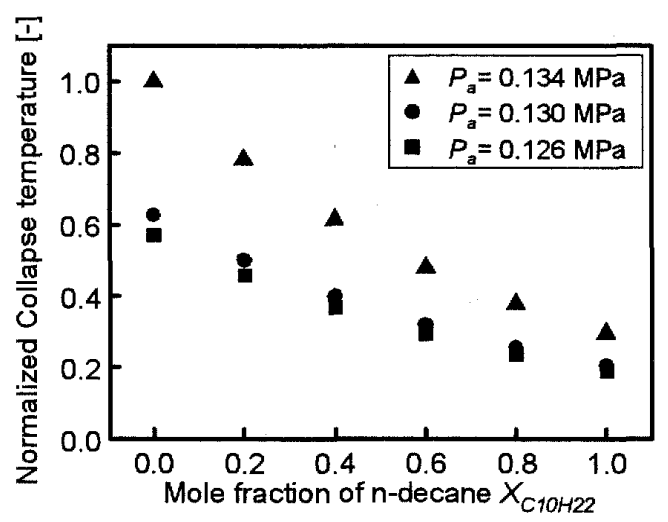

Fig.9 Calculation result for normalized collapse temperature with variable acoustic pressure for $\mathrm{Cl6} / \mathrm{ClO}$

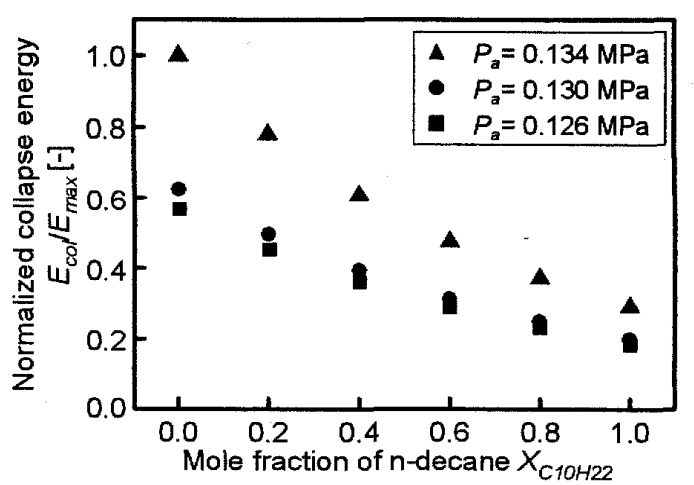

Fig.10 Calculation result for collapse energy of $C 16 / C 10$ 
ここで, $C_{v}[\mathrm{~kJ} / \mathrm{K} \cdot \mathrm{kg} \mid$ は定積比熱である. (17)式忙単一気 泡の崩壊により生じるエネルギ量を示す。

実行音压 $P_{a}=0.126,0.13,0.134 \mathrm{MPa}$ での, C16/C10 の各混合割合 $X_{C 1 \sigma}=0.0,0.2 ， 0.4 ， 0.6 ， 0.8 ， 1.0$ におけ る(17)式で求めた気泡崩壊時のエネルギを $X_{C I \sigma}=0.0$, $P_{a}=0.134 \mathrm{MPa}$ の計算值で正規化し, 図 10 に示寸。音 圧ごとに，低沸点燃料の混合割合が低下寸るにしたが い崩壊時のエネルギは増加する。この傾向は崩壊時の 温度と同一であり，気泡成長割合とは逆である，つま り，各々の気泡における崩壊時のエネルギは，気泡成 長割合より気泡内比熱比の影響が主要因である.

(17)式より算出した単一気泡における崩壊時のエネ ルギ $E_{c o l}$ に，(3)式より求めた発泡気泡数 $N(R)$ を乗じ, 溶夜内に与える全エネルギ $E_{\text {tol }}[\mathrm{kJ} / \mathrm{kg}]$ を以下に示寸よう に求めた。

$$
E_{t o l}=E_{c o l} \times N(R)
$$

(18)式が最終的に気泡崩壊により溶液に与えられた全 エネルギとなる。

\section{3. 実験条件およひ計算条件}

実験条件および計算条件を表 1 に示す．実験はガラ 不製の容器内(直径 : $22 \mathrm{~mm}$, 高さ $83.5 \mathrm{~mm}$ )に, 予めア ルゴンでバブリングを行なった然料を $15 \mathrm{~cm}^{3}$ 封入し， 密閉条件下で超音波を直接照射した. そして, 3 分ごと に，振動子付近の燃料を $1 \mu$ 少ンプルとして採取し， ガスクロマトグラフを用いて成分分析を行ない，下記 に記寸式にて，燃料改質に必要なエネルギ $E_{\text {exp }} \mathrm{kJ} / \mathrm{kg}$ 在 求めた。

$$
E_{\text {exp }}=\sum d S / d t \cdot d H \cdot V_{\text {fuel }} \cdot t_{\text {imad }}
$$

ここで, $d S / d t[\mu \mathrm{mol} /(1 \cdot \min )]$ はガスクロマトグラフから 得られた各分解生成物の生成速度, $d H[\mathrm{~kJ} /(\mathrm{mol})]$ 洛各分 解生成物を生成するのに必要なエンタルピ， $V_{\text {fwe }}\left[\mathrm{cm}^{3}\right]$ は供試然料の体積， $t_{\text {irad }}[\mathrm{min}]$ は超音波総照射時間をそ れぞれ示す.なお， $t_{\text {irad }}=12 \mathrm{~min}$ であり，気泡崩壊時 に生じたエネルギが全て燃料改質に使用したと仮定し た. また, 気泡群の背景光撮影を行ない, 気泡生成量 も調べた. その際，得られた画像から撮影領域と気泡 との比より，ボイド率を算出した。 一方，計算は 2 階 の非線形微分方程式である(10)式を 4 次の Runge-Kutta 法により解析解を求め，各値を算出した．ただし，本 論文では，発泡した気泡各々による成長または崩壊に 与える影響は考慮せず，発泡気泡全て崩壊すると仮定 しているため，定性的な考察に留める.

供試燃料に江前節と同样 $\mathrm{C} 16 / \mathrm{C} 10$ 混合燃料を用い， 混合割合は $X_{C I 0}=0.05,0.1,0.15,0.2,0.4,0.6,0.8$ と

\begin{tabular}{|c|c|c|}
\hline & Exp. & Pred. \\
\hline Test fuel volume $V_{\text {tuel }}\left[\mathrm{cm}^{3}\right]$ & 15.0 & - \\
\hline Ultrasonic frequency $f[k H z]$ & 20.0 & 20.0 \\
\hline Probe diameter $d_{\text {probe }}[\mathrm{mm}]$ & 13.0 & 13.0 \\
\hline Probe amplitude $\delta_{\text {nopos }}[\mu \mathrm{m}]$ & $31,62,93$ & $31,62,93$ \\
\hline Acoustic Pressure $P_{a}[\mathrm{MPa}]$ & $\begin{array}{c}0.126,0.130, \\
0.134\end{array}$ & $\begin{array}{c}0.126,0.130 \\
0.134\end{array}$ \\
\hline Total irradiation time $t_{\text {matal }}[\mathrm{min}]$ & 12.0 & - \\
\hline $\begin{array}{c}\text { Dissolved gas } \\
\text { (Specific heat ratio } x_{0} \text { ) }\end{array}$ & $\operatorname{Ar}(1.67)$ & $\operatorname{Ar}(1.67)$ \\
\hline Ambient pressure $P_{\text {amb }}[\mathrm{MPa}]$ & 0.101 & 0.101 \\
\hline Fuel temperature $T_{\text {fuet }}[\mathrm{K}]$ & $293.0,278.0$ & $293.0,278.0$ \\
\hline
\end{tabular}

Table 1 Experimental and numerical conditions

Table 2 Mixed fuel properties

\begin{tabular}{c|c|c|c|c|c|c|c}
\hline $\begin{array}{c}\text { Mole Fraction of } \\
\mathrm{C}_{10} \mathrm{H}_{22}\end{array}$ & 0.05 & 0.1 & 0.15 & 0.2 & 0.4 & 0.6 & 0.8 \\
\hline $\begin{array}{c}\text { Specific heat } \\
\text { ratio } \kappa\end{array}$ & 1.445 & 1.439 & 1.433 & 1.428 & 1.406 & 1.385 & 1.365 \\
\hline $\begin{array}{c}\text { Density } \\
\rho_{l}\left[\mathrm{Kg} / \mathrm{m}^{3}\right]\end{array}$ & 792 & 791 & 790 & 788 & 739 & 769 & 756 \\
\hline $\begin{array}{c}\text { Vapor Pressure } \\
P_{v}, P_{s l}[\mathrm{~Pa}]\end{array}$ & 0.61 & 2.03 & 3.8 & 6.08 & 20.27 & 42.56 & 72.95 \\
\hline $\begin{array}{c}\text { Lower vapor } \\
\text { pressure } P_{\text {sv }}[\mathrm{Pa}]\end{array}$ & 0.072 & 0.1 & 0.14 & 0.18 & 0.35 & 0.6 & 1.02 \\
\hline $\begin{array}{c}\text { Surface Tension } \\
\sigma_{l} \cdot 10^{3}[\mathrm{~N} / \mathrm{m}]\end{array}$ & 30.43 & 30.08 & 29.75 & 29.42 & 28.16 & 27.00 & 25.96 \\
\hline $\begin{array}{c}\text { Viscosity } \\
\eta_{i} 10^{6}[\mathrm{~Pa} \cdot \mathrm{s}]\end{array}$ & 3214 & 3049 & 2892 & 2742 & 2203 & 1731 & 1312 \\
\hline $\begin{array}{c}\text { Sound Speed } \\
C_{l}[\mathrm{~m} / \mathrm{s}]\end{array}$ & 1464 & 1460 & 1455 & 1450 & 1426 & 1396 & 1354 \\
\hline
\end{tabular}

\begin{tabular}{|c|c|c|c|c|c|}
\hline \multicolumn{2}{|c|}{ Test Fuel } & $\mathrm{C}_{10} \mathrm{H}_{22}$ & $\mathrm{C}_{12} \mathrm{H}_{26}$ & $\mathrm{C}_{13} \mathrm{H}_{2 B}$ & $\mathrm{C}_{16} \mathrm{H}_{34}$ \\
\hline \multicolumn{2}{|c|}{ Specific heat ratio $x[-]$} & 1.340 & 1.341 & 1.354 & 1.450 \\
\hline \multirow{3}{*}{$\begin{array}{l}\text { Density } \\
\rho_{l}\left[\mathrm{~kg} / \mathrm{m}^{3}\right]\end{array}$} & $278 \mathrm{~K}$ & 752 & 772 & 778 & S \\
\hline & $293 K$ & 738 & 759 & 765 & 794 \\
\hline & $300 \mathrm{~K}$ & & 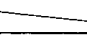 & & 788 \\
\hline \multirow{3}{*}{$\begin{array}{l}\text { Viscosity } \\
\eta_{1}[\mu \mathrm{Pa} \cdot \mathrm{s}]\end{array}$} & $278 K$ & 1199 & 2053 & 2415 & 3 \\
\hline & $293 K$ & 940 & 1540 & 1789 & 3387 \\
\hline & $300 \mathrm{~K}$ & & & & 2896 \\
\hline \multirow{3}{*}{$\begin{array}{l}\text { Sound speed } \\
C,[\mathrm{~m} / \mathrm{s}]\end{array}$} & $278 K$ & 1367 & 1405 & 1435 & -7 \\
\hline & $293 \mathrm{~K}$ & 1296 & 1335 & 1362 & 1468 \\
\hline & $300 K$ & & - & & 1431 \\
\hline \multirow{3}{*}{$\begin{array}{l}\text { Surface Tension } \\
\sigma_{i} \cdot 10^{3}[\mathrm{~N} / \mathrm{m}]\end{array}$} & $278 \mathrm{~K}$ & 26.92 & 28.87 & 29.37 & $\gamma$ \\
\hline & $293 K$ & 25.04 & 26.93 & 27.42 & 30.77 \\
\hline & $300 \mathrm{~K}$ & & & & 29.77 \\
\hline \multirow{3}{*}{$\begin{array}{l}\text { Vapor Pressure } \\
P_{\checkmark}[\mathrm{Pa}]\end{array}$} & $278 \mathrm{~K}$ & 35.7 & 2.15 & 0.658 & 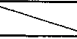 \\
\hline & $293 \mathrm{~K}$ & 120 & 9.74 & 3.45 & 0.046 \\
\hline & $300 \mathrm{~K}$ & & & & 0.117 \\
\hline
\end{tabular}

Table 3 Pure fuel properties

した. 各混合然料の物理特性は表 2 に示すとおりであ る. また比較のために, $\mathrm{n}-$ デカン $\left(\mathrm{C}_{10} \mathrm{H}_{22}\right)$, n-ドデカン $\left(\mathrm{C}_{12} \mathrm{H}_{26}\right), \mathrm{n}$-トリデカン $\left(\mathrm{C}_{13} \mathrm{H}_{28}\right), \mathrm{n}$ 一キサデカン $\left(\mathrm{C}_{16} \mathrm{H}_{34}\right) 4$ 種類の単成分然料を使用し, 表 3 亿示すように, それ ぞれ燃料温度を変更することにより，様々な物理特性 の条件下にした. なお，超音波振動子の振幅を $\delta_{\text {probe }}=31$, $62,93 \mu \mathrm{m}$ であり, それに対応する害行音圧は $P_{a}=0.126$, $0.130,0.134 \mathrm{MPa}$ である.

\section{4. 計算結果および考察}

発泡した気泡が飽和状態となる気泡生成開始から $t_{a u s}=3 \mathrm{~s}$ における実験結果より得られたボイド率の值を 
図 11(a)に，計算より得られた発泡気泡数の值を図 11(b) にそれぞれ示す. なお，闵 11(b)の発泡気泡半径は初期 気泡径の $\mathrm{R}=10[\mu \mathrm{m}]$ を用いた。 また，各図とも実行音 圧 $P_{a}=0.130 \mathrm{MPa}$ の条件である. 実験結果, 計算結果問 わずに，単成分然料，混合然料ともに飽和蒸気圧の増 大に伴ない気泡生成量が増加する。 また, 実験結果お よび計算結果ともに，混合燃料は単成分燃料に比心゙， 蒸気圧に対する気泡生成量の勾配が異なる。これは, 混合然料の蒸発特性が，飽和液体曲線がら飽和蒸気在 曲線までの圧力幅を有することにより，単成分燃料と 同じ弥気圧でも蒝発し難いことに起因寸る. 以上より,

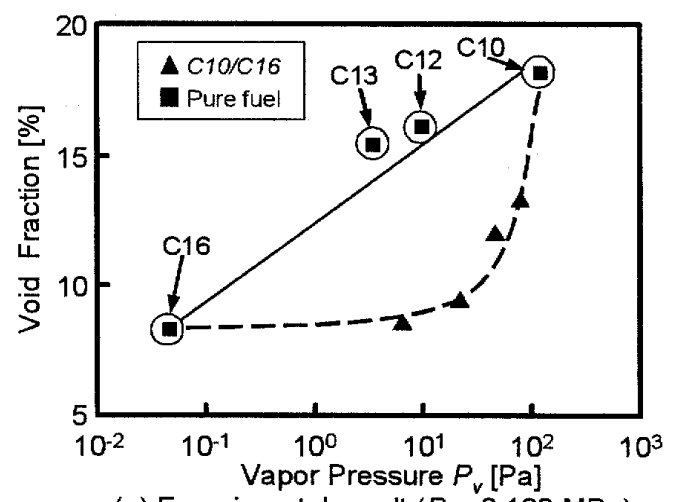

(a) Experimental result $\left(P_{a}=0.130 \mathrm{MPa}\right)$

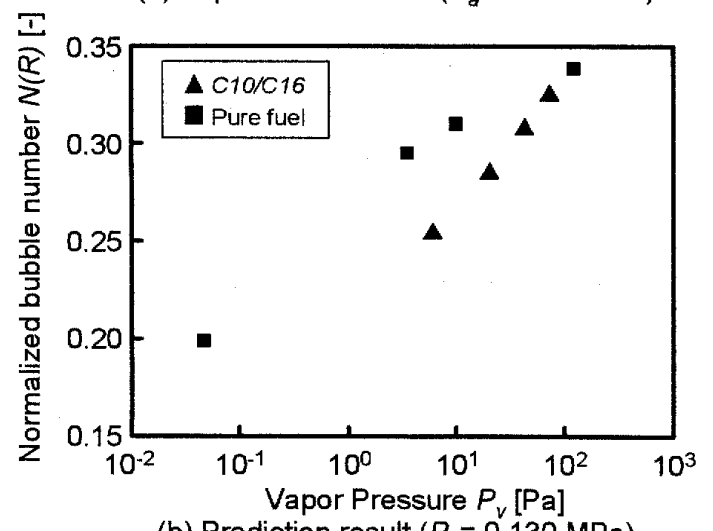

(b) Prediction result $\left(P_{\mathrm{a}}=0.130 \mathrm{MPa}\right)$

Fig. 11 Comparison of bubble number measured and predicted

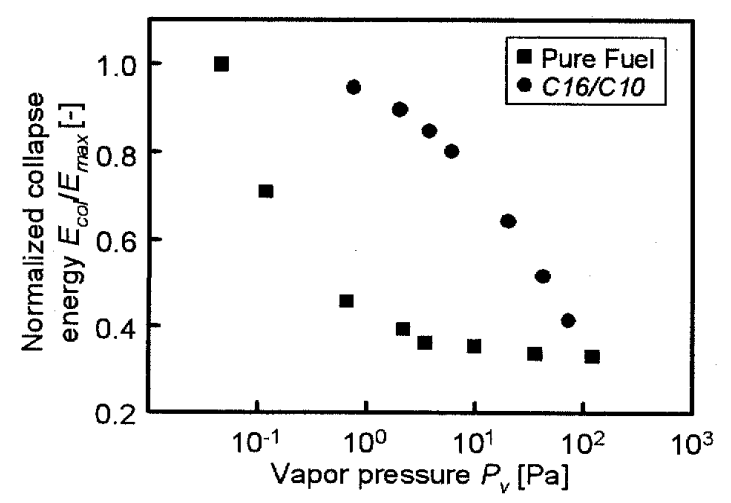

Fig. 12 Collapse energy of pure fuel and $C 16 / C 10$ $\left(P_{a}=0.126 \mathrm{MPa}\right)$
計算結果住性的な傾向が等しいことから, 実験結果 を概俩再現している.

実行音压 $P_{a}=0.126 \mathrm{MPa}$ に対して(17)式で得た各単成 分燃料およざ各 $C 16 / C 10$ 混合燃料における崩壊エネル ギの計算值と蒸気圧の関係老図 12 に示す. なお，各計 算結果は $10000[\mathrm{KJ} / \mathrm{kg}]$ オーダーである n一ヘサデカン の值で正規化している. 単成分燃料, 混合燃料ともに 蒸気圧が低下寸るにしたがい，崩壊エネルギは増加す るが，その増加率が異なる. これは，単成分燃料に比 べ混合然料の比熱比が高いかららである.

次に, C16/C10, 各振幅における(19)式で得た実験值

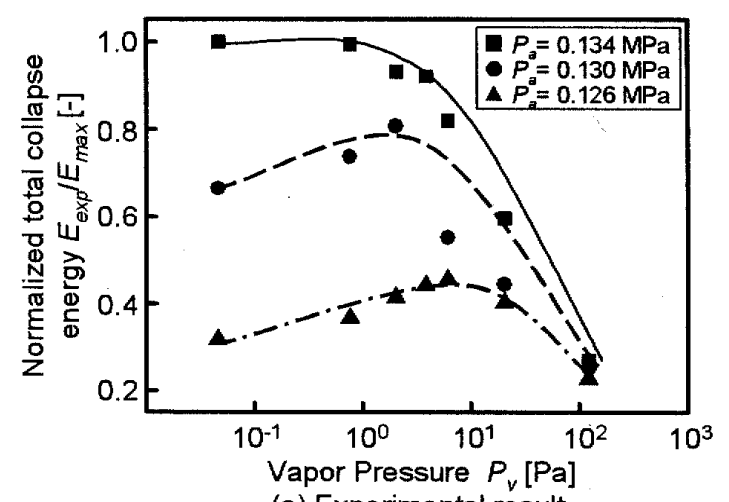

(a) Experimental result

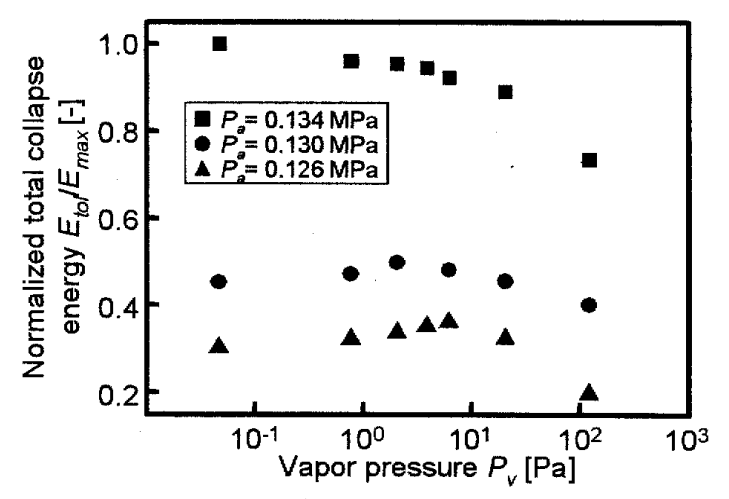

(b) Prediction result

Fig.13 Comparison of collapse energy measured and predicted

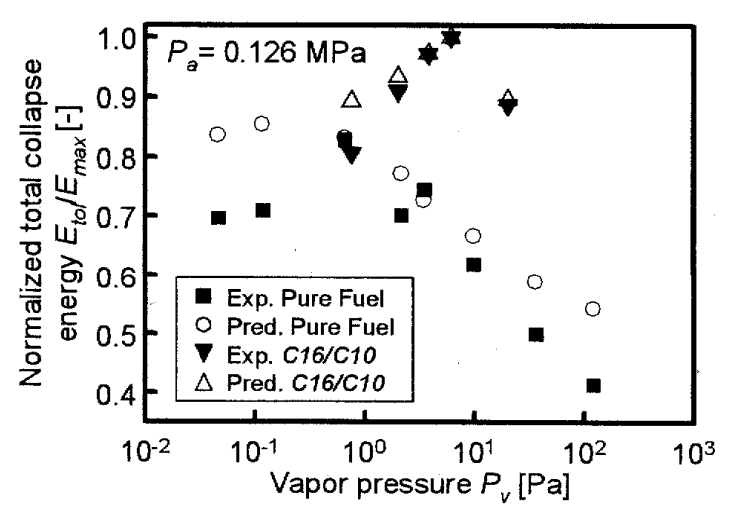

Fig.14 Comparison of bubble collapse energy measured and predicted for pure and $\mathrm{Cl} / \mathrm{Cl} / 0$ fuel 
を図 13(a)に，(18)式で得た計算值を図13(b)それぞれ示 寸. な沶, 図 $13(\mathrm{a})$ は $X_{C 10}=0.0$, 実行音压 $P_{a}=0.134 \mathrm{MPa}$ の実験值で，図 13(b)も同様の条件下での計算值でそれ ぞれ正規化した．実験結果より，振幅ごとにエネルギ が最大となる蒸気生の存在が確認でき，エネルギが最 大となる蒸気圧は，音压の低下に伴ない高くなる。一 方，計算結果においても同椂の傾向があるものの，高 蒸気王領域においては，実験結果より高いエネルギと なる. 実現象では，蒝気圧が $10[\mathrm{~Pa}]$ を超える範囲では 気泡が過剩に生成し，干涉効果を起こして改質に有効 な気泡が減少したためだと考えられる．また，計算で は，発泡気泡による音圧の減衰効果に起因寸る気泡成 長かつ崩壊の抑制を無視したからだと考えられる.

実行音圧 $P_{a}=0.126 \mathrm{MPa}$ に対し, 各 $C 16 / C 10$ 混合然料 および各単成分然料の(18)式で求めた計算結果および (19)式で求めた実験結果を図 14 に示す。なお，計算結 果は $X_{C 1 \sigma}=0.2$ の計算值で, 実験值も同様に $X_{C I \sigma}=0.2$ の 実験值でそれぞれ正規化している. 実験結果では，混 合燃料と単成分燃料のエネルギが最大となる蒸気圧が 異なり，且つ単成分燃料より混合然料のエネルギが高 く，計算結果でも同様の傾向がある，ところが，エネ ルギが最大となる蒸気圧より低蒸気任側では，実験結 果は急速に低下寸るのに対し，計算結果では緩慢であ る.これは，本モデルが発泡した気泡全てが崩壊する と仮定し，崩壊しない気泡を無視したことに起因する. しかしながら，定性的な傾向が等しいことから，気泡 崩壊時のエネルギを対象とした本モデルは，実験結果 を概わ再現している，以上より，二成分混合燃料にお けるソノケミストリーによる燃料改質では，高沸点成 分により高崩壊エネルギを得て，低沸点成分により反 応領域が拡大し，高効率な反応が実現できる.

\section{5. 結 言}

(1) ソノケミストリーにおいて，各燃料が持つ物理特 性，発泡気泡数を考慮した新たな気泡崩壊時のエ ネルギモデルを構築した。

(2) 本モデルは二成分然料の取り扱いが可能である.

(3) 揮発性の低い燃料種は気泡崩壊時に生じるエネ ルギが高いものの，気泡発泡数が少ないため，溶 液に与えられるエネルギは低くなる。

（4）比較的揮発性に富屯低沸点燃料㤌気泡発泡数が 多いものの，気泡崩罴時に生じるエネルギが低い ため，溶液に与えられるエネルギは低くなる。

(5) 計算結果から, 低沸点成分の混合に起区した重質 系然料のソノケミストリーによる然料改質は, 発 泡気泡数の増大により, 溶液に与えられるエネル
ギが高くなることを確認できた.

\section{謝辞}

本研究は, 文部科学省学術フロンティア推進事業「次 世代ゼロエミッション・エネルギー変換システム」の 支援を受けた。ここに記して謝意を表する.

\section{文献}

(1) Suslick. K. S., John J.Gawienowski, Paul F.schubert and Hau H.Wang."Alkane Sonochemistry", Joumal of Physcs Chemistry, Vol.87 (1983), pp.2299-2301.

(2) Suslick. K. S., D.A. Hammerton and R. E. Cline, Jr., The Sonochemical Hot Spot, J. Ame. Chem. Soc., Vol.108 (1986), pp.5641-5642.

(3) Price, G J., and McCollom, M., The effect of high-intensity ultrasound on diesel fuels, Ultrasonics Sonochemistry, Vol.2, No.2 (1995), pp.S67-70.

(4) D. F.Gaitan., L. A. Crum., C. C. Church., and R. A. Roy, Sonoluminescence and bubble dynamics for a single, stable cavitation bubble, J. Acoust. Soc. Am., Vol.91, No.6 (1992), pp.3166-3183.

(5) S.Hatanaka, Yasui, K, Tuziuti, T,, Kozuka, T., and H.Mitome, Influence of bubble clustering on multibubble sonoluminescence, Ultrasonics, Vol.40 (2002), pp.655-660.

(6) Yasui, K, Effect of thermal condition on bubble dynamics near the sonoluminescence threshold, J. Acoust. Soc. Am., Vol. 98 , No.5 (1995), pp.2772-2782.

(7) Löfstedt, R, Barber, B. P., Putterman, S. J., Toward a hydrodynamic theory of sonoluminescence, Phys. Fluids $A$, Vol.5, No.11 (1993), pp.2911-2928.

(8) Suslick, K. S., Sonochemistry in non-aqueous liquid, Ultrasonics, Vol.22 (1984), pp.33-36.

(9) Nolingk, B. E., Cavitation produced by ultrasonic theoretical conditions for the onset of cavitation, Proc. Phys. Soc. B, Vol.14, No.8 (1951), p. 1032.

(10) Y. Mizukoshi, H. Nakamura, H. Bandow, Y. Maeda and Y. Nagata, Sonolysis of organic liquid: effect of vapor pressure and evaporation rate, Ultrasonics Sonochemistry, Vol.6 (1999), pp.203-209.

(11) Hanada, S., Ueda, K, Wada, Y., Senda, J., Watanabe, Y., Fundamental Study on Fuel Reformulation through Sonochemistry and Phase Equilibrium Theory ( $1^{\text {st }}$ Report: Sonochemistry in Fuel), JSME B, Vol.72, No.724 (2006), pp.2984-2891.

(12) Yonezawa, T., Senda, J., Yoshiki, M, Saitou, M, Fujimoto, H., Miki, H., Behavior of Bubbles in a Vibration Field, JSME B, Vol.491, No.53 (1987), pp.1894-1899.

(13) Senda, J., Nishikori, T., Hojyo, Y. and Hujimoto, H, Modeling of Atomization and Vaporization Process in Flash Boiling Spray (1st Report, Change in Atomization Characteristics with Back Pressure), JSME B, Vol.60, No.578 (1994), pp.3551-3555.

(14) Senda, J. Nishikori, T., Hojyo, Y. and Hujimoto, H, Modelling of Atomization and Vaporization Process in Flash Boiling Spray (2nd Report, Model Analysis on Atomization and Vaporization Process), JSME B, Vol.578, No.60 (1994), pp.3556-3562.

(15) Kawano, D., Goto, Y., Odaka, M., and Senda, J., Modeling Atomization and Vaporization Processes of Flash-Boiling Spray, SAE2004-01-0534 (2004).

(16) Wada, Y., and Senda, J., Cavitation Induced Breakup Model for Multicomponent Fuel Spray, JSME B, Vol.72, No.724 (2006), pp.3113-3120.

(17) Ueda, K, Senda, J., Fundamental Study on Fuel Reformulation through Sonochemistry and Phase Equilibrium Theory ( ${ }^{\text {nd }}$ Report: High Efficiency Fuel 
Reformulation by Applying Sonochemistry into Multi-Component Fuel), JSME B, Vol. 73, No.732 (2007), pp. 1723-1730.

(18) Friend, J. F., NISTMixture Property Database Users 'Guide, (1992).

(19) Ohe, S., The Properties Constant number Prediction of engineering (in Japanese), (1985), Nikkankogyoshinbun.

(20) Saito, S., A Fundamental of Equilibrium Properties Prediction (in Japanese), (1976), , pp.143-178, Baifukan Co., LTD.

(21) Cole, R., Boiling Phenomena, Vol.1, (Hemisphere Public, Washigton, 1997), p.77.

(22) Nakamura, Ultrasonic (in Japanese), (2001), p. 176, Corona Publishing Co., LTD.

(23) Cole, R, Boiling Phenomena, Vol.1, (Hemisphere Public, Washigton, 1997), p.117.

(24) Keller, J. B., and Miksis, M., Bubble oscillation of large amplitude, J. Acoust. Soc. Am., Vol.68 (1980), pp.628-633.

(25) Kato, H, Cavitation, makisyoten, (1979), pp.21-23.

(26) Lin, H., Storey, D. B., Szeri, J. A. Rayleigh-Taylor instability of violently collapsing bubbles, Phys. Fhid, Vol.14, No.8 (2002), pp.2925-2928.

(27) Lohse, D., and Hilgenfeldt, S., Inert gas accumulation in sonoluminescing bubbles, $J$. Chem. Phys., Vol.107, No.17 (1997), pp.6986-6997.

(28) Prosperetti, A., Thermal effects and damping mechanisms in the forced radial oscillations of gas bubbles in liquids, $J$. Acoust. Soc. Am., Vol.61, No.1 (1977), pp.17-27. 